\title{
Influence of St. Petersburg urban rivers on the inflow of pollutants into the Baltic Sea
}

\author{
Stepan Klubov, and Victor Tretyakov* \\ Saint Petersburg State University, 7/9 Universitetskaya emb., 199034, St. Petersburg, Russia
}

\begin{abstract}
The results of the calculation of the inflow of pollutants into the Gulf of Finland with the outflow from Saint Petersburg watercourses are considered. Data of regular hydrochemical observations by State Unitary Enterprise "Vodokanal of Saint Petersburg" for 2018 were used for the calculation. The contribution of the megalopolis of Saint Petersburg to change of the pollutants inflow is estimated.
\end{abstract}

\section{Introduction}

Large volume of various pollutants enters the Baltic Sea with river outflows. High amounts of biogenic elements, phenols, petroleum products, and heavy metals entering the Baltic Sea with the river outflows cause its pollution and eutrophication. The main source of the pollutants is the watercourses within urbanized drainage areas. Extreme sensitivity of the Baltic Sea to anthropogenic impact is caused by its physical features [1]. Anthropogenic eutrophication of the Gulf of Finland is one of the main environmental problems of the Baltic region [2]. The process can lead to the water quality deterioration, blue-green algae development, anaerobic zones appearance, disruption of the biocenosis structure, and hydrobionts disappearance. The blue-green alga emits strongest toxins, which are dangerous for organisms, including humans [3].

Saint Petersburg is located in the Neva River delta. It is the greatest city on the Baltic Sea shore according to its population and area, which affects the Baltic Sea ecological status. Therefore, it is necessary to estimate volumes of the pollutants entering the Finnish Gulf with outflows of the rivers running through the Saint Petersburg territory that is the Saint Petersburg role in the Baltic Sea pollutants balance. Thus, the research purpose is to evaluate the contribution of Saint Petersburg area in amounts of the pollutants transported into the Finnish Gulf by the Neva River, its river branches, and other urban watercourses of the city.

\section{Methods}

The North-Western Department for Hydrometeorology and Environmental monitoring regularly monitors the hydrochemical state of Saint Petersburg urban watercourses. The Department annually assesses the inflow of biogenic elements (total nitrogen and

*Corresponding author : v_yu_tretyakov@mail.ru 
phosphorus) into the Gulf of Finland with outflow of the following rivers: the Bolshaya Neva, the Malaya Neva, the Malaya Nevka, and the Bolshaya Nevka (Fig.) [4]. The Committee for Nature Use, Environmental Protection and Ecological Safety of Saint Petersburg publishes the results of the water quality regular monitoring in the Yearbook of "Environmental protection, nature management and ensuring of environmental safety in Saint Petersburg" [4]. The results of hydrochemical analysis of water samples from the St. Petersburg water courses are used by the Department for calculation of the universal combinatorial index of water pollution for each water sampling point in accordance with the guidance document RD 52.24.643-2002 [5]. The Yearbook publishes the index values [4].

The Yearbook contains data of the inflow of biogenic elements (total nitrogen and phosphorus in tons per year) into the Gulf of Finland with the outflow of the Neva River and its branches. Hydrochemical information of the Department about the pollutants concentrations in the Saint Petersburg's watercourses is fee-paying information.

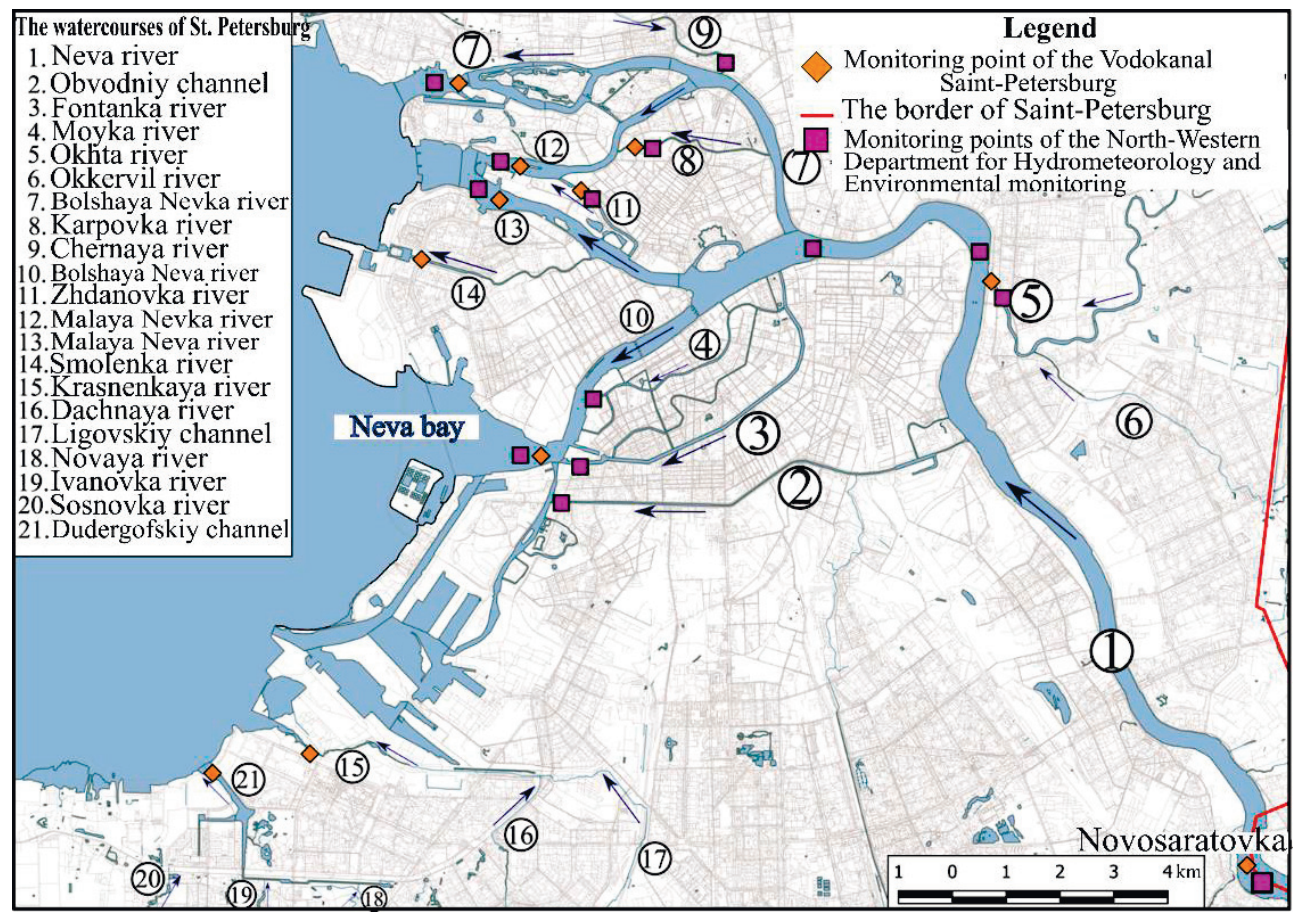

Fig. Location of water quality monitoring stations at watercourses of Saint Petersburg.

Besides the Department, "Vodokanal of Saint Petersburg" also monitors the Saint Petersburg watercourses water quality because this organization discharges wastewater. In accordance with Russian laws, a water user is obliged to monitor the water bodies. Results of the monitoring were received authors from the Committee. The hydrochemical data includes the following information:

1. Volume of wastewater and its quality for all "Vodokanal" wastewater outlets.

2. Results of water quality monitoring of the water objects with the "Vodokanal" wastewater outlets.

Information about the average annual river discharges of the St. Petersburg was obtained from monograph of R. A. Nezhikhovsky [6]. The authors made some correction of the annual river discharges taking into account the rates of stream flow in 2018. The rates in 2018 were provided by the Department at the authors' request. 
The pollutants outflows from the rivers were calculated by the authors with usage of the Vodokanal data according to [4]:

$$
Q=31,5 \cdot C_{m a} \cdot R_{m a}
$$

Here $Q$ means the outflow of some pollutant from a river, tons per year; $C_{m a}-$ average annual concentration of the pollutant in the water, grams per cubic meter; $R_{m a}$ - average annual water expenditure of the river, cubic meter per second, in 2018 [6].

The Department calculates amount of the outflows of the biogenic elements from the Neva River and its branches to the Gulf of Finland using the formula (1). The Department uses own results of the Saint Petersburg's watercourses hydrochemical monitoring. We calculated outflows of pollutants (in tons per year) into the Neva Bay (the eastern part of the Gulf of Finland) from the Neva River, its branches and tributaries using the formula (1). Data from "Vodokanal" were used for the calculations. We calculated the outflows of the following pollutants into the Gulf of Finland from the rivers of St. Petersburg: total nitrogen, total phosphorus, anionic synthetic surface-active substances (ASSAS), oil products, phenols, aluminum, iron, manganese, cuprum, zinc, mercury.

The high level of the total nitrogen and phosphorus entering the Gulf of Finland causes eutrophication of its water area. ASSAS worsens sanitary condition of the Gulf of Finland. The oil products, phenols, aluminum, and especially heavy metals have toxic effects on hydrobionts. Wastewater may have large volume with low concentrations of pollutants and otherwise it may have small volume with high concentrations of pollutants. Even low wastewater concentrations negatively affect the Gulf of Finland ecosystem because of the pollutants accumulation in the benthic sediment. For this reason, we evaluated negative impact on a water object by the mass of pollutant entering the water object with wastewater.

The mass of the pollutant entering the water body is calculated using the formula (2) [7]:

$$
M=C_{m a} \cdot V / 1000
$$

Here $M$ means the mass of pollutant entering a water body (in tons), $C_{m a}$ - average annual concentration of the pollutant in grams per cubic meter $\left(\mathrm{g} / \mathrm{m}^{3}\right)$ in wastewater, $V-$ volume of wastewater discharged per year in thousand cubic meters.

We used the mass balance method to assess the contribution of wastewater outlets, tributaries, and polluted municipal non-point runoff from the territory of St. Petersburg in the inflows of the pollutants into the Gulf of Finland. We calculated the percentages of the amounts of the pollutants entered from the various sources of contamination in the total masses of the substances incoming the Gulf of Finland with the outflow of the Neva River and its branches.

The percentages of the amounts entered into the Neva River and its branches with wastewater outlets and tributaries were calculated as following:

$$
P=M /\left(M_{l p}-M_{u p}\right) * 100
$$

Here $P$ means the percentage $(\%)$ of amount $(M)$ of some substance which entered the Neva River and its branches by tributaries $\left(M_{t}\right)$ or wastewater outlets $\left(M_{w}\right) . M_{l p}$ means amount of the substance (in tons) entering the Gulf of Finland from the Neva River and its branches, $M_{u p}$ - amount of the substance (in tons) carried by the Neva River at the hydrologic section "Novosaratovka" where the river meets the city border. 


\section{Results}

Table contains the results of our calculations. In accordance with it, the amounts of the pollutants in the Neva River and its branches increase after transiting the territory of Saint Petersburg. The amounts of petroleum products and total iron increase more than 10 per cent. The volumes of total phosphorus, aluminum, and copper transported by the Neva River and its branches increase more than 20 per cent. The amount of zinc transferred by the Neva River within the Saint Petersburg area increased over three-fold. Obviously, these changes are caused by anthropogenic impact. A very high inflow of zinc into the Neva River and its tributaries within the city area can be explained by the process of rainwater runoff contamination by galvanized city roofs and drainpipes. The polluted rainwater runoff flows into the Neva River and its tributaries.

The increases are caused by various sources: the wastewater outlets, the tributaries, and the polluted municipal non-point runoff. The wastewater is the main source of phenol entering the Neva River and its branches. Other pollutants enter the Neva River mainly from its tributaries. Assessment of the pollutants inflows into the city's watercourses within sheet flooding (land runoff) from the city area must be the subject of additional research.

Table. Results of the author's calculations of the pollutants in flows into the Gulf of Finland from the Neva River and its branches in 2018 according to the monitoring data of "Vodokanal".

A - The pollutants outflows from the Neva River and its branches into the Gulf of Finland, in tons per year

B - Changes of amounts of the substances transported by the Neva River and its branches through the city area, in \% ("+"means some increase of the substance amount after transiting Saint Petersburg, "-" - decrease)

$\mathrm{C}$ - Contributions of wastewater from "Vodokanal" outlets into the changes of amounts of the pollutants transported by the Neva River and its branches through the city area, in $\%$.

D - Contributions of the tributaries into the changes of amounts of the pollutants transported by the Neva River and its branches through the city area, in $\%$.

\begin{tabular}{|l|c|c|c|c|}
\hline & A, ton per year & $\mathrm{B}, \%$ & $\mathrm{C}, \%$ & $\mathrm{D}, \%$ \\
\hline Total nitrogen & 80090 & $+4,4$ & 1,50 & 46,39 \\
\hline Total phosphorus & 2446 & $+25,7$ & 1,11 & 23,20 \\
\hline ASSAS & 1022 & $+5,0$ & 9,38 & 46,01 \\
\hline Oil products & 4246 & $+13,5$ & 0,47 & 10,97 \\
\hline Phenols & 22,1 & $+8,3$ & 64,36 & 14,56 \\
\hline Aluminum & 6569 & $+33,5$ & 0,11 & 14,22 \\
\hline Iron & 11432 & $+10,5$ & 0,02 & 64,04 \\
\hline Manganese & 997 & $-46,4$ & $<0$ & $<0$ \\
\hline Cuprum & 498 & $+67,4$ & 0,05 & 2,07 \\
\hline Zinc & 2241 & $+223,8$ & 0,03 & 0,55 \\
\hline Mercury & 1,0 & $+7,7$ & 0,22 & 12,08 \\
\hline
\end{tabular}

The research was supported by the RFBR grant 19-05-00683-a "Theoretical and methodological substantiation, mathematical apparatus and models for integral assessment of aquatic objects ecological status and ecological wellbeing". The authors thank the management and employees of the North-Western Department for Hydrometeorology and Environmental monitoring and State Unitary Enterprise "Vodokanal of Saint Petersburg" for providing the data. 


\section{References}

1. T. Potapova, E. Dzhinoridze, V. Koroleva, V. Bogdanov, I. Shmeleva. St. Petersburg U. Earth Sc.. 7, 76-86 (2005)

2. E. Stepanova, G. Frumin, Russ. J. Gen. Chem., 84, 2592-2595 (2014)

3. N. Hrisanov, G. Osipov. Management of eutrophication of water bodies (Hydrometeoizdat, 1993)

4. I. Grigoriev, I. Serebritsky. Yearbook of the Committee for Nature Use, Environmental Protection and Ecological Safety (Sezam-Print, 2018)

5. Method of comprehensive assessment of the degree of pollution of natural waters by hydrochemical parameters, the guidance document RD 52.24.643-2002 (Roshydromet, 2002)

6. RR. Nezhikhovsky. Neva river and Neva Bay (Hydrometeoizdat, 1981)

7. About calculation and collection of fees for negative impact on the environment (Resolution of the Government of the Russian Federation № 255 of 3.03.2017) 